\title{
Customer Satisfaction Level of Islamic Bank and Conventional Bank in Pakistan
}

\author{
${ }^{1}$ muslim Khan, ${ }^{2}$ suhail Ahmad \\ ${ }^{1}$ Executive development centre, Gandhara University Peshawar, Pakistan \\ ${ }^{2}$ Department of management studies, University of Malakand, KPK, Pakistan
}

\begin{abstract}
Islamic banking has been started function in 1970s. The speed of the growth of Islamic banking all over the world including Pakistan has been expedited since 2002. The objective of this study is to explained/find the phenomenon that conventional banking, which has been operating for the last three centuries have started tumbling steeply in the last few decades while Islamic banking has been extend their function all over the world specially in Muslim countries with quickly. This study shows the customer satisfaction level of both Islamic and conventional Banking in Pakistan. The population of this study is consists of customer of Islamic banking and conventional banking in Pakistan. Three Islamic banks i.e., Bank of Khyber, Almeezan bank and Albaraka bank and three conventional banks i.e. Habib bank limited, united bank limited and Allied bank limited were selected for this study. And 100 questionnaires were distributed among employees of these banks. Islamic banks are getting popularity due to interest free products, risk sharing activities and strong ties with the religion. Islamic banks work as welfare organization to promote trade and economic activities in line with the instructions of Islam to provide a number of Interest-free products and service. The existence of Islamic and conventional banks in Pakistan created stiff competition among banks to attract and retain greater number of customers by the provision of quality services. This study examined the relationship among service quality, customer satisfaction and bank performance by comparing Islamic and conventional banks operating in Pakistan.
\end{abstract}

Key Words. Bank performance, customer satisfaction, conventional bank, Islamic bank, service quality

\subsection{Islamic banking}

\section{Introduction}

Islamic banking has been started function in 1970s. They grow continuously and play important role all over the world, in 2009 Islamic banking industry has reached 1.0 trillion US dollars. International Rating Agency, Standard \& Poor estimates that Islamic financial industry has potential to grow to $\$ 4.0$ trillion over medium term. It is surprising to note that global conventional banks likes Standard Chartered Bank (SCB)Deutsche Bank, Citibank, etc, have also set up separate Divisions to structure or produce Islamic financial products and are offering Islamic banking services to their Muslim customers and even to those non-Muslim customers who are interested in profit and loss sharing (PLS) financial instruments. It means they provide equal services for all religions. France, China, UK Singapore and many other countries have. developed special regulatory to facilitate the working of Islamic banking. The speed of the growth of Islamic banking all over the world including Pakistan has been expedited since 2002.

The objective of this study is to explained/find the phenomenon that conventional banking, which has been operating for the last three centuries have started tumbling steeply in the last few decades while Islamic banking has been extend their function all over the world specially in Muslim countries with quickly . The vertical growth of Islamic banking within short of time has surprised everyone including western financial experts and analysts. A massive research activity has been initiated all over the world to probe this phenomenon. Nazim Ali (2008:154) says that many books have been published on Islamic Banks. This small discussion shows the growing interest of researchers in Islamic Banks.

It is better to note that conventional banking has been declining continuously. Even now it is in serious crisis and suffering huge losses. The western countries are also paying huge fiscal cost of conventional banking crisis.

Islamic banking growth is very wide. Interest in this discipline has proliferated to almost 60 countries, going beyond the Islamic world to the leading global financial centers. For quite some time, United Kingdom has adopted open policy and provided a level playing field to Islamic banking new boundaries and new frontiers. Leading Islamic banks have fast spread their network from home base to develop a regional and global reach. Some of the Middle East banks are now entering into African and Central Asian markets and are sizing up Australian financial market. 


\subsection{Conventional Banking}

Conventional banking system had its borne from Italy and then transfer to Spain and other countries. But the profession grows out of the trade and function started from of the commercial revolution of the High Middle Ages (1000-1350). By the early modern period, however, banking spread throughout Europe and became complex and increasingly involved in credit transactions. During the thirteenth and fourteenth centuries there were three types of banks:

1. International merchant banks;

2. Local deposit banks, and

3. Pawn broking establishments.

These kinds were not exclusive: the same customers sometimes engaged in two or all three types simultaneously. According to the Florentine banking system (FBS) fell into crisis in the sixteenth century, Italians remained active in international banking into the seventeenth century. In the meantime, banking on the Italian model grew in southern Germany and other country of Europe. The most notable of the firms was the great Fugger Banking Companies of Augsburg named after Hans Fugger, a renowned trader of fourteen century weaver. These banks were engaged in a range of activities, including speculation in the money market and trade in commodities. The conventional banking system that was originated in Italy and then transfer to Spain and then to Holland, until it settled in England. The commercial activity in England was motivated by a group of Lombardian traders emigrated from Italy in the $14^{\text {th }}$ century A.D. The new comers settled in that part of London which is known today as the famous Limbard Street. With their arrival in London, the most important part of banking operations, the documentary credit and lending operation of usury were commenced. Most of these emigrants were Jews.

\section{Objectives of the Study}

- To compare the customer satisfaction of Islamic and conventional banking in Pakistan.

- To find out the factor that causes customers satisfaction in Islamic banking and conventional banking.

- To provide effective strategies for improving Islamic and conventional banking.

\section{Literature Review}

Islamic Bank in conventional banks both create competition among the different banks to satisfied customers and fulfill their needs / expectation requirements and long term benefits for the economy. The conventional banks and Islamic banks are different from one another commonly on the basis of their goals. Riba and risk sharing practices Islamic banks follows by the Quran and Sunnah as Pakistan is Muslim country and having the population of $96 \%$ of the Muslims.

In Pakistan Islamic banks are endeavoring to capture the maximum number of customers to compete with the conventional banks by the facilitating their customers a large number of product and services as an alternative for interest base products. Banks are providing a large number of product and services and facing though competition to attract potential customers. Perception quality of services, availability of services, and confidence in bank in social and religious factors are playing a motivational role towards Islamic banks. (Haque Osman Zaki, Hj Ismais 2009) this idea determines and find out those factor that influences the customer towards Islamic banks in Malaysia. Banks are need to better understand and provide information to their customer into continuously evaluate their service quality and order to maintain their market share ( Tabnoun and Hussein 2002) they written to find out the performance of interest free banks and interest base banks with respect liquidity risk credit risk and profitability during the year 1992 to 2001. This study is the comparison of interest base banks and interest free banks in Bahrain (Abdus Saman 2004). According to the kamal and Naser Ahmad Jamal and Khalid Al Khatib in (1999) they tried to get the information /awareness of the customers and provide instructions/information from the IBS products they had taken a sample of 206 respondents and come to the conclusion that most of the customers have a little bit knowledge about the specific products such as Mudarabah and murabaha. But most of them do not use these products (Nasir at all 1999)

\section{Research Methodology}

This study shows the customer satisfaction level of both Islamic and conventional Banking in Pakistan. The population of this study is consists of customer of Islamic banking and conventional banking in Pakistan.

\subsection{Universe of the study:}

For this study some Islamic banks and conventional banks are selected i-e.

\begin{tabular}{|l|l|}
\hline ISLAMIC BANKS & CONVENTIONAL BANKS \\
\hline Bank of Khyber (Islamic Branches) & Habib Bank limited \\
\hline Meezan Islamic Bank & United Bank limited \\
\hline Albaraka Islamic Bank & Allied Bank limited \\
\hline
\end{tabular}


4.2 Data Collection:

For this study Primary data can be collected through interview and questionnaire.

4.3 Sample Design: collection.

A sample of 100 Questionnaires will distributed among selected bank's customer randomly for data

\section{Conclusion And Recommendations}

Islamic banks are getting popularity due to interest free products, risk sharing activities and strong ties with the religion. Islamic banks work as welfare organization to promote trade and economic activities in line with the instructions of Islam to provide a number of Interest-free products and service. The existence of Islamic and conventional banks in Pakistan created stiff competition among banks to attract and retain greater number of customers by the provision of quality services. This study examined the relationship among service quality, customer satisfaction and bank performance by comparing Islamic and conventional banks operating in Pakistan. It is found that customer satisfaction level is found high in Conventional bank as compared to Islamic bank, because of good global image, high varieties of products awareness programs and many other activities. It is very strong and functioning from very beginning. The people are reliance upon conventional banking; it provides different varieties of products to customers. Advance technologies also play a key role in their promotion.

Islamic banking annually growth rate is $114 \%$ according to State Bank of Pakistan. But it is new and not that much financially strong which is required. People having religious oriented mind like Islamic banking system. Conventional banking is highly awareness level compared to Islamic banking. Because it is very old financial system. Reliability is also another factor of its promotion among individuals. It is financially strong comparatively to Islamic banking. Profit oriented people are like conventional banking system.

\section{Recommendations:}

It is recommended that managers should improve the quality of services to retain their customers as satisfied customers for long-term benefits. Similarly, they should make arrangements to enhance awareness among customers and employees of banks for improvement of their products and services to enhance performance. Islamic banks should develop marketable products according to Islamic instructions to compete with conventional banks.

Islamic banking is needed awareness program among people in country that to know every individual who are doing business with banks are familiar about it. Because people are not aware about it. So a comprehensive awareness campaigns is required for the promotion of Islamic banking. It is also required for Islamic banking to set up their branches at every small city of different areas; because to provide their services to individuals at their door step. It is also necessary to introduce new services to people. It is required for Islamic banking to financially strong and reduces transaction time and provide different type of products to customers; because to attract the customers towards Islamic banking. Conventional banking is required to reduce their interest. And it is also required to reduce their service charges. For more improving it is necessary to provide online facilities in every branch.

\section{References}

[1]. Abdus Samad(2004), "Performance of interest-free Islamic banks vis-a-vis interestbased conventional banks of Bahrain" Journal of Economics and Management 12, no.2 (2004):

[2]. Ahasanul Haque, Jamil Osman and Ahmad Zaki Hj Ismail (2009) "Factor Influences Selection of Islamic Banking: A Study on Malaysian Customer Preferences.” American Journal of Applied Sciences 6 (5): 922-928, 2009 ISSN 1546-9239

[3]. Khan, M.S.N., Hassan, M. K., \& Shahid, A I. (2008). "Banking behavior of Islamic bank customer in Bangladesh. Journal of Islamic Economics, Banking and Finance", 159-194.

[4]. Mamunur Rashid and M. Kabir Hassan(2009), "Customer Demographics Affecting

[5]. Bank Selection Criteria, Preference, and Market Segmentation: Study on Domestic Islamic Banks in Bangladesh.”. International Journal of Business and Management Vol. 4 No. 6 
DATA FOR ISLAMIC BANK:

\section{Data Analysis Tables}

Table 4.1: Gender.

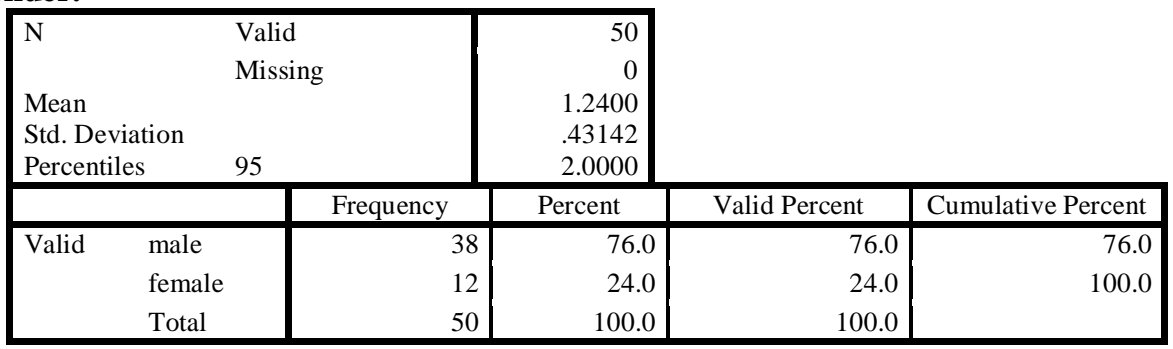

Table 4.2: Marital status.

\begin{tabular}{|l|r|}
\hline N $\quad$ Valid & 50 \\
Mean & 0 \\
Std. Deviation & 1.7000 \\
Percentiles $\quad 95$ & .46291 \\
\hline
\end{tabular}

\begin{tabular}{|ll|r|r|r|r|}
\hline & \multicolumn{1}{|c|}{ Frequency } & \multicolumn{1}{|c|}{ Percent } & Valid Percent & Cumulative Percent \\
\hline Valid & unmarried & 15 & 30.0 & 30.0 & 30.0 \\
& married & 35 & 70.0 & 70.0 & 100.0 \\
& Total & 50 & 100.0 & 100.0 & \\
\hline
\end{tabular}

Table 4.3: Age group.

\begin{tabular}{|ll|r|}
\hline $\mathrm{N}$ & Valid & 50 \\
& Missing & 0 \\
Mean & & 2.9400 \\
Std. Deviation & & .65184 \\
Percentiles & 95 & 4.0000 \\
\hline
\end{tabular}

\begin{tabular}{|c|c|c|c|c|c|}
\hline & & Frequency & Percent & Valid Percent & Cumulative Percent \\
\hline \multirow[t]{5}{*}{ Valid } & (18 to 25$)$ & 1 & 2.0 & 2.0 & 2.0 \\
\hline & (25 to 35 ) & 9 & 18.0 & 18.0 & 20.0 \\
\hline & (35 to 45$)$ & 32 & 64.0 & 64.0 & 84.0 \\
\hline & (45 to 55$)$ & 8 & 16.0 & 16.0 & 100.0 \\
\hline & Total & 50 & 100.0 & 100.0 & \\
\hline
\end{tabular}

Table 4.4: Qualification.

\begin{tabular}{|ll|r|}
\hline $\mathrm{N}$ & Valid & 50 \\
& Missing & 0 \\
Mean & & 3.5800 \\
Std. Deviation & & 1.03194 \\
Percentiles & 95 & 5.0000 \\
\hline
\end{tabular}

\begin{tabular}{|ll|r|r|r|r|}
\hline & Frequency & Percent & Valid Percent & Cumulative Percent \\
\hline Valid & Metric & 3 & 6.0 & 6.0 & 6.0 \\
& Intermediate & 4 & 8.0 & 8.0 & 14.0 \\
Graduate & 11 & 22.0 & 22.0 & 36.0 \\
Master & 25 & 50.0 & 50.0 & 86.0 \\
above Master & 7 & 14.0 & 14.0 & 100.0 \\
Total & 50 & 100.0 & 100.0 & \\
\hline
\end{tabular}


Table 4.5: Profession.

\begin{tabular}{|ll|r|}
\hline N & Valid & 50 \\
& Missing & 0 \\
Mean & & 2.4800 \\
Std. Deviation & & .88617 \\
Percentiles & 95 & 4.0000 \\
\hline
\end{tabular}

\begin{tabular}{|ll|r|r|r|r|}
\hline & Frequency & Percent & Valid Percent & Cumulative Percent \\
\hline Valid & Student & 3 & 6.0 & 6.0 & 6.0 \\
& Govt. Employee & 30 & 60.0 & 60.0 & 66.0 \\
private Employee & 7 & 14.0 & 14.0 & 80.0 \\
business owner & 10 & 20.0 & 20.0 & 100.0 \\
Total & 50 & 100.0 & 100.0 & \\
\hline
\end{tabular}

Table 4.6: level of Income.

\begin{tabular}{|l|r|}
\hline N & Valid \\
Missing & 50 \\
Mean & 0 \\
Std. Deviation & 2.8400 \\
Percentiles 95 & .65027 \\
\hline
\end{tabular}

\begin{tabular}{|c|c|c|c|c|c|}
\hline & & Frequency & Percent & Valid Percent & Cumulative Percent \\
\hline \multirow[t]{5}{*}{ Valid } & Less than 10000 & 3 & 6.0 & 6.0 & 6.0 \\
\hline & 10,000 to 25,000 & 6 & 12.0 & 12.0 & 18.0 \\
\hline & 25,000 to 40,000 & 37 & 74.0 & 74.0 & 92.0 \\
\hline & More than 40,000 & 4 & 8.0 & 8.0 & 100.0 \\
\hline & Total & 50 & 100.0 & 100.0 & \\
\hline
\end{tabular}

Table 4.7: The transaction speed is fast or slow in Islamic Bank?

\begin{tabular}{|ll|r|}
\hline $\mathrm{N}$ & Valid & 50 \\
& Missing & 0 \\
Mean & & 2.7000 \\
Std. Deviation & & .95298 \\
Percentiles & 95 & 4.4500 \\
\hline
\end{tabular}

\begin{tabular}{|ll|r|r|r|r|}
\hline & Frequency & Percent & Valid Percent & Cumulative Percent \\
\hline Valid & very low & 7 & 14.0 & 14.0 & 14.0 \\
& low & 9 & 18.0 & 18.0 & 32.0 \\
medium & 28 & 56.0 & 56.0 & 88.0 \\
high & 4 & 8.0 & 8.0 & 96.0 \\
very high & 2 & 4.0 & 4.0 & 100.0 \\
Total & 50 & 100.0 & 100.0 & \\
\hline
\end{tabular}

Table 4.8: Management of Islamic Bank is Satisfactory?

\begin{tabular}{|ll|r|}
\hline $\mathrm{N}$ & Valid & 50 \\
& Missing & 0 \\
Mean & & 2.7400 \\
Std. Deviation & & .85261 \\
Percentiles & 95 & 4.4500 \\
\hline
\end{tabular}

\begin{tabular}{|ll|r|r|r|r|}
\hline & Frequency & Percent & Valid Percent & Cumulative Percent \\
\hline Valid & very low & 3 & 6.0 & 6.0 & 6.0 \\
& low & 15 & 30.0 & 30.0 & 36.0 \\
medium & 26 & 52.0 & 52.0 & 88.0 \\
high & 4 & 8.0 & 8.0 & 96.0 \\
very high & 2 & 4.0 & 4.0 & 100.0 \\
Total & 50 & 100.0 & 100.0 & \\
\hline
\end{tabular}


Table 4.9: Availability of Financial advice of Islamic bank is how much?

\begin{tabular}{|ll|r|}
\hline N & Valid & 50 \\
& Missing & 0 \\
Mean & & 2.4400 \\
Std. Deviation & .88433 \\
Percentiles 95 & 4.4500 \\
\hline
\end{tabular}

\begin{tabular}{|ll|r|r|r|r|}
\hline & \multicolumn{1}{|c|}{ Frequency } & \multicolumn{1}{|c|}{ Percent } & Valid Percent & Cumulative Percent \\
\hline Valid & very low & 4 & 8.0 & 8.0 & 8.0 \\
& low & 27 & 54.0 & 54.0 & 62.0 \\
medium & 14 & 28.0 & 28.0 & 90.0 \\
high & 3 & 6.0 & 6.0 & 96.0 \\
very high & 2 & 4.0 & 4.0 & 100.0 \\
Total & 50 & 100.0 & 100.0 & \\
\hline
\end{tabular}

Table 4.10: knowledge to customer.

\begin{tabular}{|ll|r|}
\hline $\mathrm{N}$ & Valid & 50 \\
& Missing & 0 \\
Mean & & 2.2200 \\
Std. Deviation & & .99571 \\
Percentiles & 95 & 4.4500 \\
\hline
\end{tabular}

\begin{tabular}{|ll|r|r|r|r|}
\hline & Frequency & Percent & Valid Percent & Cumulative Percent \\
\hline Valid & very low & 10 & 20.0 & 20.0 & 20.0 \\
& low & 27 & 54.0 & 54.0 & 74.0 \\
& medium & 7 & 14.0 & 14.0 & 88.0 \\
high & 4 & 8.0 & 8.0 & 96.0 \\
very high & 2 & 4.0 & 4.0 & 100.0 \\
Total & 50 & 100.0 & 100.0 & \\
\hline
\end{tabular}

Table 4.11: Awareness program is satisfactory or not?

\begin{tabular}{|c|c|c|}
\hline $\mathrm{N}$ & Valid & 50 \\
\hline & Missing & 0 \\
\hline & & 1.7600 \\
\hline & ion & 1.13497 \\
\hline Percentiles & 95 & 5.0000 \\
\hline
\end{tabular}

\begin{tabular}{|cc|c|c|c|c|}
\hline & Frequency & Percent & Valid Percent & Cumulative Percent \\
\hline Valid & very low & 28 & 56.0 & 56.0 & 56.0 \\
& low & 14 & 28.0 & 28.0 & 84.0 \\
& medium & 3 & 6.0 & 6.0 & 90.0 \\
high & 2 & 4.0 & 4.0 & 94.0 \\
very high & 3 & 6.0 & 6.0 & 100.0 \\
Total & 50 & 100.0 & 100.0 & \\
\hline
\end{tabular}

Table 4.12: Customers Confidence level on Islamic bank.

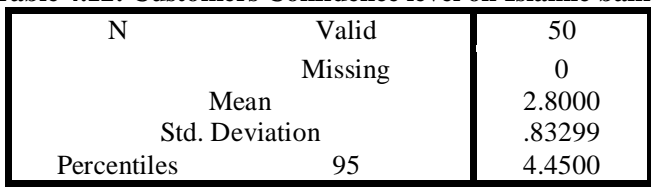

\begin{tabular}{|cc|c|c|c|c|}
\hline & Frequency & Percent & Valid Percent & Cumulative Percent \\
\hline Valid & very low & 3 & 6.0 & 6.0 & 6.0 \\
& low & 12 & 24.0 & 24.0 & 30.0 \\
& medium & 29 & 58.0 & 58.0 & 88.0 \\
high & 4 & 8.0 & 8.0 & 96.0 \\
very high & 2 & 4.0 & 4.0 & 100.0 \\
Total & 50 & 100.0 & 100.0 & \\
\hline
\end{tabular}


Table 4.13: Service charges of Islamic bank.

\begin{tabular}{|c|c|c|}
\hline \multicolumn{1}{|c|}{ N } & Valid & 50 \\
& Missing & 0 \\
& Mean & 1.6000 \\
\multicolumn{2}{|c|}{ Std. Deviation } & 1.06904 \\
Percentiles & 95 & 4.4500 \\
\hline
\end{tabular}

\begin{tabular}{|cc|c|c|c|c|}
\hline & Frequency & Percent & Valid Percent & Cumulative Percent \\
\hline Valid & very low & 34 & 68.0 & 68.0 & 68.0 \\
& low & 8 & 16.0 & 16.0 & 84.0 \\
& medium & 4 & 8.0 & 8.0 & 92.0 \\
high & 2 & 4.0 & 4.0 & 96.0 \\
very high & 2 & 4.0 & 4.0 & 100.0 \\
Total & 50 & 100.0 & 100.0 & \\
\hline
\end{tabular}

DATA ANALYSIS FOR CONVENTIONAL BANK:

Table 4.1: Gender

\begin{tabular}{|cc|c|}
\hline N & Valid & 50 \\
& Missing & 0 \\
& \multicolumn{1}{c|}{ Mean } & 1.4200 \\
\multicolumn{2}{|c|}{ Std. Deviation } & .49857 \\
Percentiles & 95 & 2.0000 \\
\hline
\end{tabular}

\begin{tabular}{|cc|c|c|c|c|}
\hline & Frequency & Percent & Valid Percent & Cumulative Percent \\
\hline \multirow{2}{*}{ Valid } & male & 29 & 58.0 & 58.0 & 58.0 \\
& female & 21 & 42.0 & 42.0 & 100.0 \\
& Total & 50 & 100.0 & 100.0 & \\
\hline
\end{tabular}

Table 4.2: Marital Status.

\begin{tabular}{|c|c|c|}
\hline $\mathrm{N}$ & Valid & 50 \\
\hline & Missing & 0 \\
\hline & & 1.5400 \\
\hline & & .50346 \\
\hline Percentiles & 95 & 2.0000 \\
\hline
\end{tabular}

\begin{tabular}{|cc|c|c|c|c|}
\hline & Frequency & Percent & Valid Percent & Cumulative Percent \\
\hline \multirow{2}{*}{ Valid } & unmarried & 23 & 46.0 & 46.0 & 46.0 \\
& married & 27 & 54.0 & 54.0 & 100.0 \\
& Total & 50 & 100.0 & 100.0 & \\
& & &
\end{tabular}

Table 4.3: Age Group.

\begin{tabular}{|c|c|c|}
\hline $\mathrm{N}$ & Valid & 50 \\
\hline & Missing & 0 \\
\hline & & 3.1400 \\
\hline & & .75620 \\
\hline Percentiles & 95 & 4.0000 \\
\hline
\end{tabular}

\begin{tabular}{|cc|c|c|c|c|}
\hline & Frequency & Percent & Valid Percent & Cumulative Percent \\
\hline Valid & $(18$ to 25$)$ & 1 & 2.0 & 2.0 & 2.0 \\
& $(25$ to 35$)$ & 8 & 16.0 & 16.0 & 18.0 \\
& $(35$ to 45$)$ & 24 & 48.0 & 48.0 & 66.0 \\
& $(45$ to 55$)$ & 17 & 34.0 & 34.0 & 100.0 \\
& Total & 50 & 100.0 & 100.0 & \\
\hline
\end{tabular}




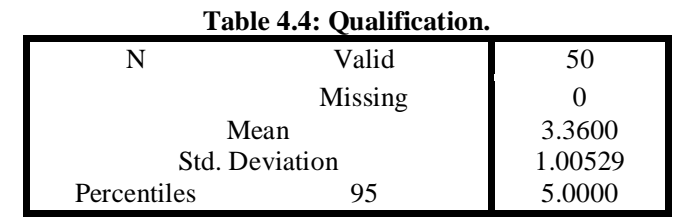

\begin{tabular}{|c|c|c|c|c|c|}
\hline & & Frequency & Percent & Valid Percent & Cumulative Percent \\
\hline \multirow[t]{6}{*}{ Valid } & metric & 3 & 6.0 & 6.0 & 6.0 \\
\hline & intermediate & 4 & 8.0 & 8.0 & 14.0 \\
\hline & Graduate & 21 & 42.0 & 42.0 & 56.0 \\
\hline & Master & 16 & 32.0 & 32.0 & 88.0 \\
\hline & above master & 6 & 12.0 & 12.0 & 100.0 \\
\hline & Total & 50 & 100.0 & 100.0 & \\
\hline
\end{tabular}

Table 4.5: Profession.

\begin{tabular}{|c|c|c|}
\hline $\mathrm{N}$ & Valid & 50 \\
\hline & Missing & 0 \\
\hline & & 3.0800 \\
\hline & & 1.04667 \\
\hline Percentiles & 95 & 4.0000 \\
\hline
\end{tabular}

\begin{tabular}{|cc|c|c|c|c|}
\hline & & Frequency & Percent & Valid Percent & Cumulative Percent \\
\hline Valid & student & 3 & 6.0 & 6.0 & 6.0 \\
& Govt .employee & 16 & 32.0 & 32.0 & 38.0 \\
& private employee & 5 & 10.0 & 10.0 & 48.0 \\
business owner & 26 & 52.0 & 52.0 & 100.0 \\
& Total & 50 & 100.0 & 100.0 & \\
\hline
\end{tabular}

Table 4.6: level of Income.

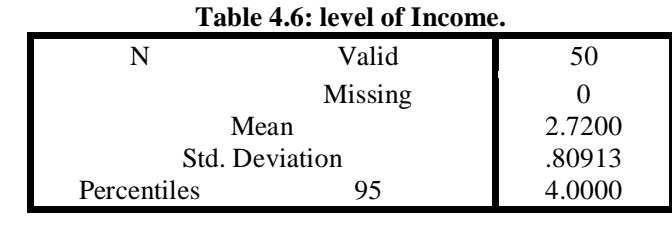

\begin{tabular}{|cc|c|c|c|c|}
\hline & Frequency & Percent & Valid Percent & Cumulative Percent \\
\hline Valid & Less than 10,000 & 4 & 8.0 & 8.0 & 8.0 \\
& 10,000 to 25,000 & 13 & 26.0 & 26.0 & 34.0 \\
& 25,000 to 40,000 & 26 & 52.0 & 52.0 & 86.0 \\
More than 40,000 & 7 & 14.0 & 14.0 & 100.0 \\
Total & 50 & 100.0 & 100.0 & \\
\hline
\end{tabular}

Table 4.7: Transaction speed of Conventional bank is fast or slow?

\begin{tabular}{|c|c|c|}
\hline $\mathrm{N}$ & Valid & 50 \\
\hline & Missing & 0 \\
\hline & & 4.3000 \\
\hline & & 1.03510 \\
\hline Percentiles & 95 & 5.0000 \\
\hline
\end{tabular}

\begin{tabular}{|cc|c|c|c|c|}
\hline & Frequency & Percent & Valid Percent & Cumulative Percent \\
\hline Valid & very low & 1 & 2.0 & 2.0 & 2.0 \\
& low & 1 & 2.0 & 2.0 & 4.0 \\
& medium & 12 & 24.0 & 24.0 & 28.0 \\
& high & 4 & 8.0 & 8.0 & 36.0 \\
very high & 32 & 64.0 & 64.0 & 100.0 \\
Total & 50 & 100.0 & 100.0 & \\
\hline
\end{tabular}


Table 4.8: Management of Conventional Bank is satisfactory?

\begin{tabular}{|cc|c|}
\hline $\mathrm{N}$ & Valid & 50 \\
& Missing & 0 \\
& \multicolumn{1}{|c|}{ Mean } & 4.4800 \\
\multicolumn{2}{|c|}{ Std. Deviation } & .93110 \\
Percentiles & 95 & 5.0000 \\
\hline
\end{tabular}

\begin{tabular}{|cc|c|c|c|c|}
\hline & Frequency & Percent & Valid Percent & Cumulative Percent \\
\hline Valid & very low & 1 & 2.0 & 2.0 & 2.0 \\
& low & 1 & 2.0 & 2.0 & 4.0 \\
& medium & 6 & 12.0 & 12.0 & 16.0 \\
high & 7 & 14.0 & 14.0 & 30.0 \\
& very high & 35 & 70.0 & 70.0 & 100.0 \\
Total & 50 & 100.0 & 100.0 & \\
\hline
\end{tabular}

Table 4.9: Availability of financial advice to customers

\begin{tabular}{|cc|c|}
\hline $\mathrm{N}$ & Valid & 50 \\
& Missing & 0 \\
& \multicolumn{1}{|c|}{ Mean } & 4.2200 \\
\multicolumn{2}{|c|}{ Std. Deviation } & .81541 \\
Percentiles & 95 & 5.0000 \\
\hline
\end{tabular}

\begin{tabular}{|cc|c|c|c|c|}
\hline & Frequency & Percent & Valid Percent & Cumulative Percent \\
\hline Valid & very low & 1 & 2.0 & 2.0 & 2.0 \\
& low & 1 & 2.0 & 2.0 & 4.0 \\
& medium & 3 & 6.0 & 6.0 & 10.0 \\
high & 26 & 52.0 & 52.0 & 62.0 \\
very high & 19 & 38.0 & 38.0 & 100.0 \\
Total & 50 & 100.0 & 100.0 & \\
\hline
\end{tabular}

Table 4.10: Knowledge to customers.

\begin{tabular}{|cc|c|}
\hline $\mathrm{N}$ & Valid & 50 \\
& \multicolumn{1}{|c|}{ Missing } & 0 \\
& \multicolumn{1}{|c|}{ Mean } & 3.8400 \\
\multicolumn{2}{|c|}{ Std. Deviation } & .86567 \\
Percentiles & 95 & 5.0000 \\
\hline
\end{tabular}

\begin{tabular}{|cc|c|c|c|c|}
\hline & Frequency & Percent & Valid Percent & Cumulative Percent \\
\hline Valid & very low & 2 & 4.0 & 4.0 & 4.0 \\
& low & 2 & 4.0 & 4.0 & 8.0 \\
& medium & 5 & 10.0 & 10.0 & 18.0 \\
& high & 34 & 68.0 & 68.0 & 86.0 \\
very high & 7 & 14.0 & 14.0 & 100.0 \\
Total & 50 & 100.0 & 100.0 & \\
\hline
\end{tabular}

Table 4.11: Awareness program to customers about Conventional bank.

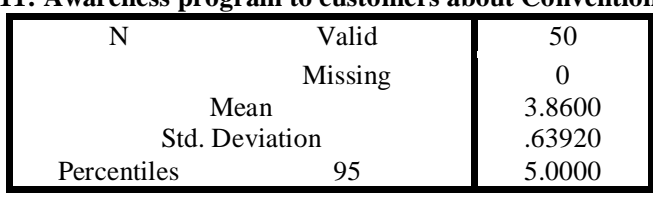

\begin{tabular}{|cc|c|c|c|c|}
\hline & Frequency & Percent & Valid Percent & Cumulative Percent \\
\hline Valid & very low & 1 & 2.0 & 2.0 & 2.0 \\
& low & 1 & 2.0 & 2.0 & 4.0 \\
& medium & 5 & 10.0 & 10.0 & 14.0 \\
high & 40 & 80.0 & 80.0 & 94.0 \\
& very high & 3 & 6.0 & 6.0 & 100.0 \\
Total & 50 & 100.0 & 100.0 & \\
\hline
\end{tabular}


Table 4.12: Customers confidence on Conventional Bank.

\begin{tabular}{|cc|c|}
\hline N & Valid & 50 \\
& Missing & 0 \\
& \multicolumn{1}{|c|}{ Mean } & 4.4600 \\
\multicolumn{2}{|c|}{ Std. Deviation } & .97332 \\
Percentiles & 95 & 5.0000 \\
\hline
\end{tabular}

\begin{tabular}{|cc|c|c|c|c|}
\hline & Frequency & Percent & Valid Percent & Cumulative Percent \\
\hline Valid & very low & 1 & 2.0 & 2.0 & 2.0 \\
& low & 2 & 4.0 & 4.0 & 6.0 \\
medium & 5 & 10.0 & 10.0 & 16.0 \\
high & 7 & 14.0 & 14.0 & 30.0 \\
& very high & 35 & 70.0 & 70.0 & 100.0 \\
Total & 50 & 100.0 & 100.0 & \\
\hline
\end{tabular}

Table 4.13: Service charges.

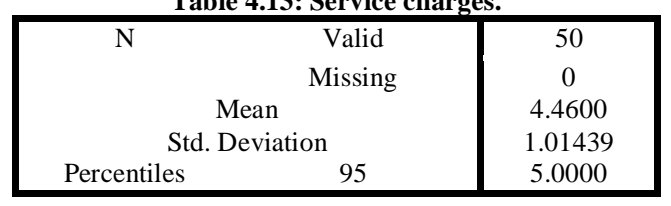

\begin{tabular}{|c|c|c|c|c|c|}
\hline & & Frequency & Percent & Valid Percent & Cumulative Percent \\
\hline \multirow[t]{6}{*}{ Valid } & very low & 2 & 4.0 & 4.0 & 4.0 \\
\hline & low & 1 & 2.0 & 2.0 & 6.0 \\
\hline & medium & 4 & 8.0 & 8.0 & 14.0 \\
\hline & high & 8 & 16.0 & 16.0 & 30.0 \\
\hline & very high & 35 & 70.0 & 70.0 & 100.0 \\
\hline & Total & 50 & 100.0 & 100.0 & \\
\hline
\end{tabular}

